\title{
Transpired Solar Collectors
}

\section{This simple, low-cost solar} technology preheats ventilation air for commercial buildings

Most industrial and commercial buildings require large quantities of ventilation air to maintain a healthy work environment. In many regions, this ventilation air needs to be heated throughout the fall, winter, and spring to provide a comfortable work environment. Transpired solar collectors, developed jointly during the last decade by researchers at the National Renewable Energy Laboratory (NREL) and engineers at Conserval Systems, Inc., are a reliable, low-cost technology for preheating building ventilation air. With simple payback periods ranging from 3 to 12 years and an estimated 30-year life span, transpired collector systems offer building owners substantial cost savings.

As the system schematic on the next page shows, the simplicity of the transpired collector design is striking. In a typical application, a large portion of a building's

\section{Highlights}

Converts as much as $80 \%$ of available solar radiation to heat

Ideal for use in sunny climates with long heating seasons

Installed cost: \$6 per square foot in new construction; $\$ 10$ in retrofit applications

- Payback periods range from 3 to 12 years depending on climate and type of fuel being displaced

Estimated 30-year system life

More than 35 systems installed since 1992. south-facing wall is clad with dark-colored, perforated metal sheeting, which performs as a large solar collector. The sheeting is mounted to the building's structural wall, creating a 4- to 6-inch gap between the two. As outside air is drawn through the collector's perforations by ventilation fans, its temperature increases by as much as $40^{\circ} \mathrm{F}\left(22^{\circ} \mathrm{C}\right)$. The heated air flows to the top of the wall, where it is distributed to the building's interior through conventional ductwork.

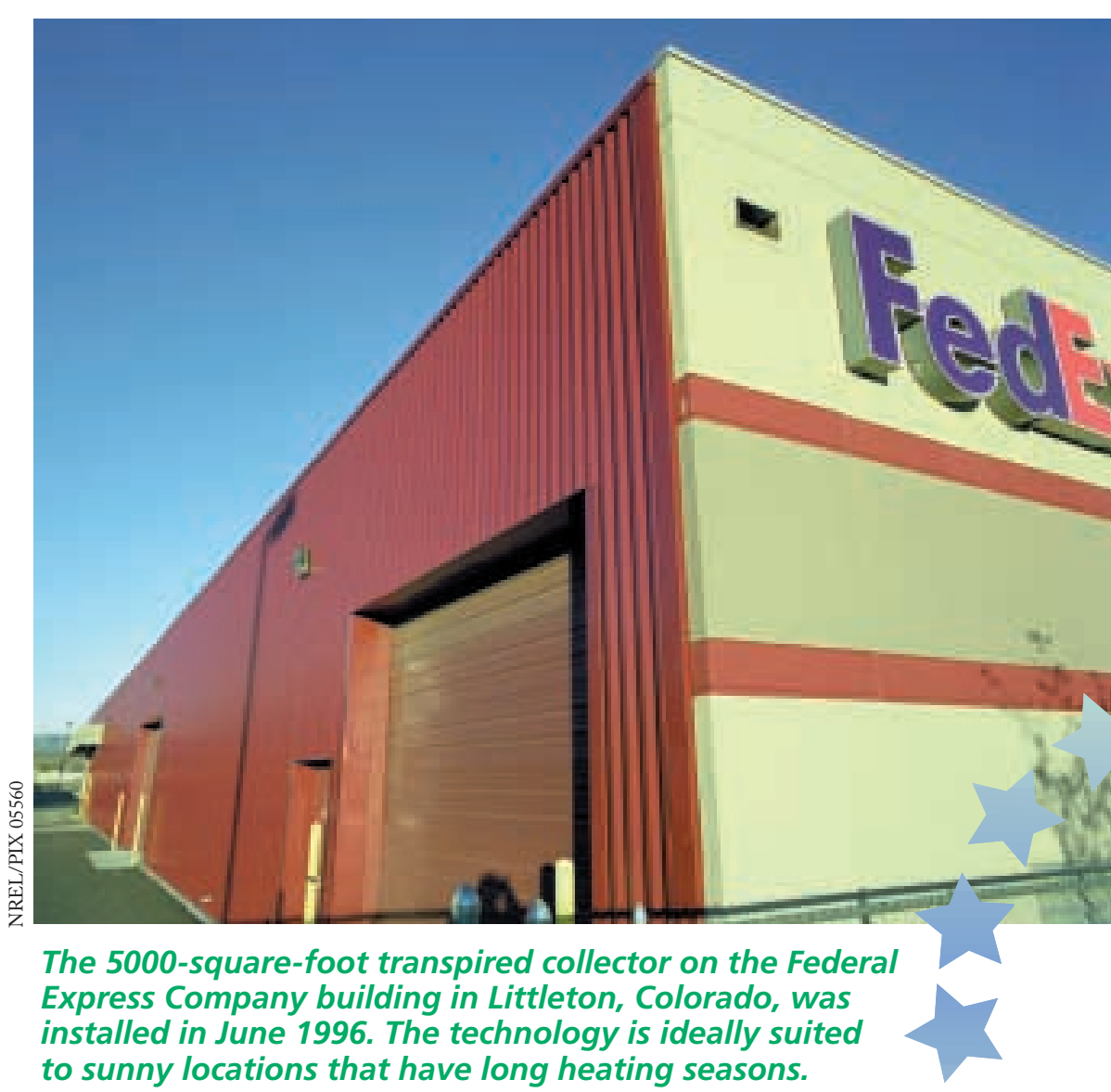
installed in June 1996. The technology is ideally suited to sunny locations that have long heating seasons. 
Transpired collectors

provide the most

reliable, best performing, and lowest cost solar

heating for commercial and industrial buildings available on the market today.

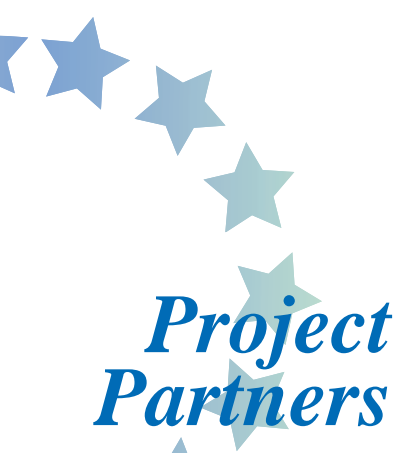

U.S. Department of Energy

Conserval Systems, Inc.

National Renewable Energy Laboratory

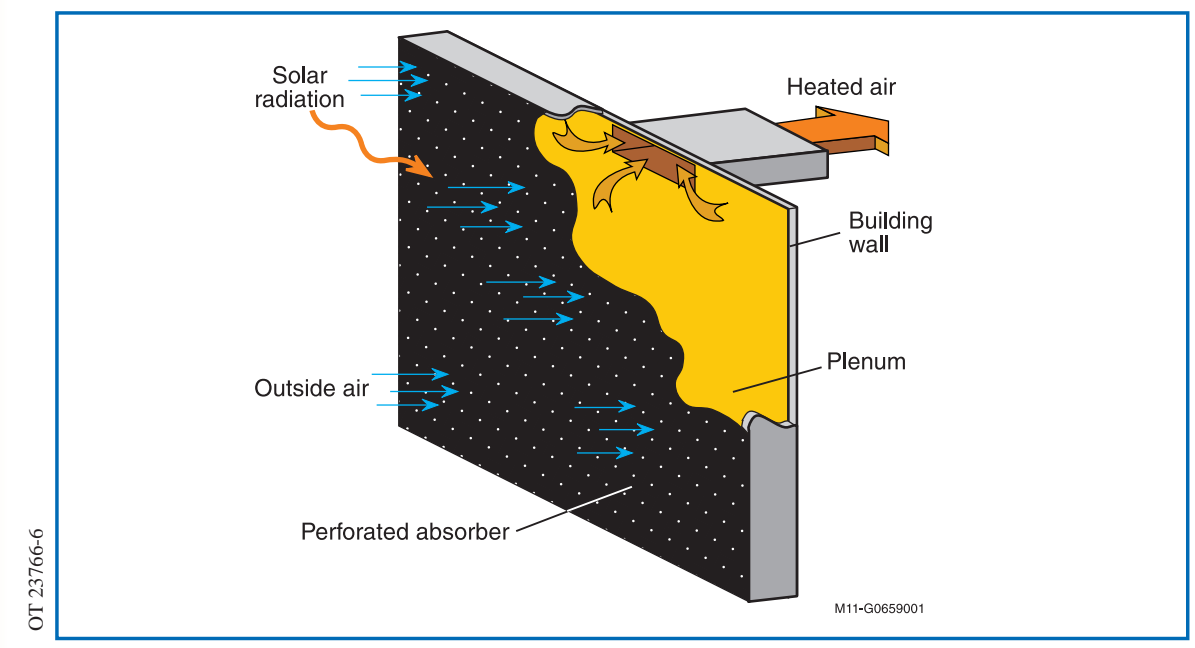

With the exception of the fans, the transpired collector has no moving parts and requires no maintenance.

\section{For More Information:}

Visit DOE's Solar Buildings Program Web site at: www.eren.doe.gov/solarbuildings

or contact:

Energy Efficiency and Renewable Energy Clearinghouse (EREC) P.O. Box 3048

Merrifield, VA 22116 (800)-DOE-EREC www.eren.doe.gov/consumerinfo/ email:doe.erec@nciinc.com

Federal Technology Alerts:

Transpired Collectors (Solar Preheaters for Outdoor Ventilation).

DOE/GO-10098-528 April, 1998. www.eren.doe.gov/femp/prodtech/tranfta1.html systems since 1992. Ford, General Motors, Federal Express, and McDonnell Douglas are on the growing list of industrial users of this technology.

Transpired collectors have also caught the attention of the research community. In 1994, NREL and Conserval were jointly awarded $R E D D$ Magazine's prestigious R\&D 100 Award for their work developing the technology, and Popular Science magazine assessed the transpired collector as one of the 100 most important technology advances of 1994.
Transpired Air Collectors: Ventilation Preheating. DOE/GO 10098-558, 1998 www.nrel.gov/docs/fy99osti/24499.pdf

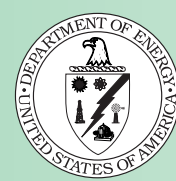

Produced for the U.S. Department of Energy 1000 Independence Avenue, SW Washington, DC 20585

by the

National Renewable Energy Laboratory a DOE national laboratory

DOE/GO-10098-466

September 1998, revised August 2000

Printed with renewable-source ink on paper containing at least 50\% wastepaper, including $20 \%$ postconsumer waste 